\title{
Efficiency evaluation in forest management - a literature review
}

\author{
Wojciech Młynarski, Adam Kaliszewski* \\ Forest Research Institute, Department of Forest Management, Sękocin Stary, ul. Braci Leśnej 3, 05-090 Raszyn, Poland \\ *Tel. +48 22 7150678, fax +48 22 7153837, e-mail: A.Kaliszewski@ibles.waw.pl
}

\begin{abstract}
The aim of our work was to give an overview on efficiency evaluation in forest management as described in the literature. Here we present definitions for efficiency and productivity of economic entities as well as categories of efficiency evaluation methods and discuss ratio analysis, parametric and non-parametric approaches to measure efficiency in forestry. With regards to ratio analysis, we focused on reports employing this approach in Poland due to the abundant literature on this subject. On the other hand, studies based on parametric and non-parametric approaches for efficiency evaluation in the forest sector have only been used occasionally in Poland and thus this part of our analysis is based on research done abroad. The most important parametric method is the Stochastic Frontier Approach (SFA), while the most important non-parametric approach involves Data Envelopment Analysis (DEA), which was developed at the end of the 1970s and utilizes a mathematical programming algorithm.

Our review shows that efficiency evaluation in forest management in Poland so far is mostly based on ratio analysis. However, although those methods are of considerable practical importance, in terms of scientific development they are now being replaced by more mathematically and statistically advanced parametric and non-parametric methods, which also open up more opportunities to analyze the efficiency of forest management. The first research employing non-parametric DEA recently published in Poland is a good step towards improving research quality and provides comprehensive results for the efficiency evaluation of forest management.
\end{abstract}

Keywords: efficiency analysis, ratio analysis, parametric approach, non-parametric approach

\section{Introduction}

The term management refers to an action aimed at fulfilling unlimited human needs by means of limited resources in a way assuring the best possible satisfaction (Szoege 2005). In the case of a forest holding, management amounts to carrying on specific activities to enable the fulfilment of all forest functions (productive and non-productive).

The transformation of the command-and-distribution (central) economy into the demand-supply (market) system, initiated in the early 1990s in Poland, was the major challenge for forestry. In order to successfully operate under economic competition, the State Forests National Forest Holding (PGLLP) - the largest and leading forest management entity in Poland - was forced to undertake a number of measures to improve own economic conditions. Amongst others, the focus was on the decentralisation of management, optimisa- tion of the size of forest districts' area, sale of unnecessary infrastructure and reduction of labour costs through employment reduction as well as a necessity to contract private sector services (Kocel 2013). At the same time, the State Forests were obligated to conduct forest management in a sustainable way, equally taking into account environmental, social and economic aspects. Article 50 of the Forest Act (1991) obliges PGLLP to operate in accordance with the principle of self-financing and cover the costs of activities undertaken from its own revenues. Therefore, the production function (economic) has become the basis of Poland's contemporary forest management, and material goods produced and sold cover the costs of maintaining forest non-productive functions (Klocek 2003).

The efficiency of forest management is a result of the processes taking place in the forest holding determined by inputs (production factors) and effects (forest production).

Received: 11.04.2018, reviewed: 16.05.2018, accepted: 29.08.2018. 
The role of the forest holding is to search for ways to obtain the most favourable (optimal) ratio between the expenditures incurred and the achieved results (Klocek, Płotkowski 2009). It usually boils down to strive to maximise the effects at certain expenses (the principle of the highest efficiency) or to minimise the expenditures in order to achieve the expected results (the principle of saving). The main tool used to consider and assess these aspects is the economic analysis, which, adjusted to the specificity of forest management and taking into account a broad spectrum of indicators, should be the foundation of rational financial management in forestry.

The aim of the present article is to review Polish and foreign subject literature with respect to the assessment of forest management efficiency. Relevant research has been carried out for several decades. The search for new assessment methods for economic units' activities and all-inclusive analysis of management efficiency may contribute to more efficient management of forestry enterprises. This article presents the definitions of the efficiency and productivity of forestry entities as well as the methods used in efficiency assessments, such as ratio analysis, as well as parametric and non-parametric methods presented in scientific literature on the subject. Owing to rich literature on the ratio analysis methods used in efficiency assessments of forest management, we focused on the results of studies carried out in Poland. As studies using parametric and non-parametric methods with reference to forestry have been rather conducted by foreign authors, the pertinent part of our article presents their research results. Owing to the broad scope of the issue of assessing the efficiency of forest management, as well as volume restrictions of this article, the topics presented in our review are generally addressed, and the results of our analysis should be treated as complementary. Nonetheless, the results presented point to both thus far comprehension of the efficiency of a range of aspects of Poland's forest management as well as current trends in research and methods used in Europe and in the world.

\section{The concept of efficiency}

Efficiency is one of the most important aspects with regards to the assessment of economic entities. It is a multi-faceted term with numerous synonymous expressions. The term 'efficiency' is derived from the Latin language (effectivus), which means 'taking effects or producing results' (Bańko 2010). In everyday language, efficiency is equated with performance, efficiency, productivity or capability (Bańko 2005).

The definitions for efficiency quoted in subject literature are more or less precise. Each of them presents a separate concept in terms of understanding as well as expression and measurement mode (Bielski 2004). In economic practice, the most common definition refers to economic efficiency (ma- nagement efficiency). It reflects the result of economic activity determined by the ratio of useful output to input of the production factor/factors (Bellinger 2007). Samuelson and Nordhaus (2017) defined efficiency as the most effective utilisation of public resources in the process of satisfying people's shortcomings and needs with no wastage. An efficient economy goes on when a given production cannot be increased without reducing other production (production-possibility frontier). In the praxeological approach, efficiency is defined as 'a positive feature attributed to activities that give a positively evaluated result, regardless of whether the result was or was not intended' (Pszczołowski 1978). According to Spruch (1984), the term management efficiency expresses 'the quantified (by means of economic indicators) result, achieved in so far activity or anticipated ability to meet specific social needs in an economically efficient manner', whereby the scope of social needs met by the enterprise should be consistent with the objectives of its establishment and expressed in such quantity or value of products and services that can be achieved by means of the strengths and resources possessed, in a way that ensures their rational issuance. Sulmicki (1978) considered a company to be fully efficient if it makes full use of its resources to manufacture products determined by the market demand, without unnecessary stockpiling.

The concept of efficiency is often equated and used interchangeably with the concept of productivity. Both terms, although closely related to each other, are not identical (Ray 2004). Productivity expresses the ratio of production volume produced and sold in the analysed period to the amount of used or consumed output resources, that is, the relation of output to input. Such approach is easily applied in theory and practice when one type of effort contributes to one effect. The situation becomes more complicated in economic entities in which the activity consists in producing many products (outcomes) at the expense of many inputs, as in the case of the PGLLP. In this situation, the total productivity is determined, that is, the ratio of the total amount of production (products) to the total amount of resources (outlays) involved in generating products (Kosieradzka 2004). Literature also includes the concepts of absolute and relative productivity. The absolute (average) productivity describes the actual ratio of outputs to inputs, whereas the relative productivity is the quotient of the productivity of a given entity to the productivity of another (Wolszczak-Derlacz 2013).

\section{Methods of assessing efficiency}

Depending on the type of information used, methods for assessing the efficiency of economic entities are distinguished into three groups: ratio analysis, parametric methods and non-parametric methods (Guzik 2009). 
Efficiency assessed using the methods based on indicators is determined by means of ratio analysis that compares particular indices. Then the efficiency of an economic entity is for the most part related to determining the entity's financial condition, that is, assessing its financial status and efficiency (Dudycz, Wrzosek 2003). There are four groups of economic indicators in the most commonly used classification: solvency (debt), efficiency of asset use (turnover, operational efficiency), profitability (sales, assets, capital) and liquidity (Buraczewski, Wysocki 1997, 2000; Ćwiąkała-Małys, Nowak 2009). In addition, some authors refer to the capital market indicator (Pomykalska, Pomykalski 2007). However, the latter serves the purpose of assessing joint stock companies that issue securities (shares) and trade them on the stock exchange.

The parametric approach to the efficiency evaluation involves the use of neoclassical production function to determine the maximum production volume, taking into account the factual level of inputs (Triantis 1990). The parameters of this function (shape and position) are most often determined using econometric estimation methods (e.g. regression analysis). The production function determines the efficiency curve, and deviations from this curve are the result of random errors and inefficiency. The methods used in the parametric approach differ with respect to assumptions regarding random error distribution and inefficiency (Pawłowska, Kozak 2008). This group of methods includes the stochastic frontier approach (SFA), distribution-free approach (DFA) and thick frontier approach (TFA) (Ćwiąkała-Małys, Nowak 2009).

Efficiency assessment using non-parametric methods involves the linear programming procedures, without taking into account the impact of the random factor on the efficiency of entities and possible measurement errors (Szymańska 2010). Non-parametric methods using these procedures include data envelopment analysis (DEA) and the free disposal hull (FDH) (Ćwiąkała-Małys, Nowak 2009).

DEA makes use of mathematical programming algorithm and was published at the end of the 1970s (Charnes et al. 1978). DEA is primarily used to assess the relative technical efficiency of decision-making units (DMUs; the effectiveness of the DMU is measured against other objects from the studied group). DMUs are responsible for transforming outlays into effects, and, therefore, DEA may be used in the assessment of the effectiveness of various types of entities (Wolszczak-Derlacz 2014). The transformation of resources (inputs) into the products and services in the production unit is affected by many external factors (exogenous) - the so-called environmental variables (Bogetoft, Otto 2011).

The term 'data envelopment analysis' has not been uniformly translated into Polish and is usually referred to as 'analiza otoczki danych' (Prędki 2003), 'analiza obwiedni danych' (Guzik 2009) or 'analiza danych granicznych' (Ćwiąkała-Małys, Nowak 2009).

\section{Assessment of management efficiency in forestry}

The principle of rational management (the principle of economy) was formulated with reference to a capitalist enterprise. It refers to proceedings aimed at making optimal choices to accomplish the utmost implementation of the goal with the means at hand or minimising the effort to achieve a given degree of implementation. The principle of rational management is of great importance in forest management. The achievement of different effects of economic activity by the forest districts that operate under comparable production conditions is not a rare or exceptional phenomenon (Kwiecień, Kocel 2006, Kocel, Kwiecień 2010). It results from the existence of a number of factors directly affecting management efficiency. Some of them, such as staff knowledge and professional qualifications, can be directly shaped by supervisors of organisational units and, at the same time, are the cheapest and most effective 'inputs' that allow to increase the efficiency of management. However, many factors are beyond the direct influence of managerial personnel, and these include, for example, forest stand species composition and age structure as well as forest site climatic and topographic conditions (Marszałek 1975).

Management efficiency reflects economic efficiency and means the ratio of the effect obtained (output) to the incurred outlay (input). In forest management, the inputs are the resources of individual production factors and current costs, whereas outputs take various forms, depending on the functions performed by the forest and forest holding. In principle, two categories of outputs can be distinguished: (1) those as a result of economic functions fulfilled by the forest and forest holding and (2) those arisen from infrastructural (indirect economic and non-market) functions fulfilled by the forest and forest holding. The inputs of the first group play a key role, which include, aside from forest products (wood and non-wood products), changes in the standing volume of growing stock (Marszałek 1975).

When assessing the forest management efficiency, it is necessary to evaluate the effectiveness of investment, that is, to compare inputs and outputs related to the determination of potential variants of economic decision aimed at achieving the intended profits. The ratio analysis as well as the parametric and non-parametric methods discussed earlier serve this purpose.

\subsection{Ratio analysis}

In Poland, initial studies on application of ratio analysis to assess forest management efficiency were undertaken in the 1970s by Prof. Tadeusz Marszałek who described the use 
of economic efficiency calculations with respect to selected economic activities. The author distinguished two categories of efficiency indices: (a) outlays, including costs of production, as well as viability, profitability, accumulative rate and profit rate; (b) resources, taking into account forest use and productivity as well as forest holding profitability (Marszałek 1974, 1975).

Andrzejczyk (1979) addressed the issue of forest management efficiency as well and developed a series of efficiency indices of pine stand production based on the data on the efficiency of the production of pine growing stock volume. The aim of this study was to develop a methodological basis for 'the economic assessment of efficiency of tree stand production under specific, natural-economic and organisational conditions of forest production'. The study proved that factors such as forest site type, stand quality as well as rotation significantly influence the efficiency of timber production in pine stands.

Szramka (1982) carried out a study to determine the efficiency of production and labour. This author proposed a number of relative indices based on the assumption that the assessment of the economic use of production resources (production efficiency) should be separated from the economic use of current outlays (work efficiency). In order to obtain the comparability of labour efficiency indices and to take into account diverse natural conditions of forests managed by the forest districts, in his later studies, the author applied differently constructed corrective coefficients and tested their usefulness. The construction of the coefficients was based on two partial coefficients, taking into account the basic categories of costs in the forest districts (Szramka 1989).

Also, Podgórski (1989) conducted a research on forest production efficiency. He distinguished two categories of forest production: 'around growing volume stock' and 'growing volume stock'. The production output in the first category comprised the timber sale value adjusted with the use of values regarding final cutting area and harvest cutting size. The second category reflected growing stock volume, calculated as the difference between the amounts of current annual increment and annual harvest cutting. The obtained values were the basis for the construction of absolute partial indices of production efficiency.

In the period of economic transformation in Poland, the first study on the efficiency of forest management was carried out by Szramka (1992). The author conducted a preliminary analysis and proposed the classification of labour determinants. The latter were divided into the primary determinants, resulting from the conditions of forest production, and the secondary determinants - resulting from the primary determinants and market laws. As part of the secondary determinants, technical-organisational and economic factors were distinguished. In his later studies, the author used financial indi- cators. In the analysis of management efficiency of the forest districts within the Regional Directorate of the State Forests in Szczecinek, a correction factor Q was applied to verify the calculated labour efficiency indicators. It allowed to include the costs of diversified production incurred by the surveyed districts in the analyses. The results showed that in the period covered by the analysis, that is, in the years 1990-1991, a significant increase in the gross profit was observed, reflected in the increase of the average profitability ratio (Szramka 1995).

A subsequent study carried out by Szramka (1996) focused on the assessment of efficiency of forest districts in view of new regulations on financial management in the State Forests. The analysis of the financial condition of the forestry districts administered by the Regional Directorate of the State Forests in Piła included, inter alia, income, costs, current assets and profit-earning capacity, as well as viability and profitability indices. The results obtained showed that during the studied period (1991-1993), definite decrease in labour efficiency occurred, and in addition, the costs of individual forest management activities were overstated.

In the first half of the 1990s, research conducted under the direction of Prof. Stefan Arbatowski (Arbatowski et al. 1994) focused on the variant assessment of the efficiency of the State Forests' economic performance. The calculation of forest production efficiency, using efficiency indicators, was carried out for three variants. The indices used were formulated based on the sales of goods and services in connection with game damage in stands and housing. In conclusion, the authors postulated the use of the developed methodology in the analyses of the annual market and the status of financial management in all the Regional Directorates of the State Forests (Arbatowski et al. 1994).

The study by Podgórski and Kikayi (1996) was carried out to determine the forest productivity using technical and economic forestry indices. The forestry technical indices included: volume of timber growing, stand volume, current stand increment, final cutting area and final cutting size. Forestry economic indices included different variants of forest productivity. The authors stated that the indices used in the study could constitute the basis for concluding about forest productivity.

Szramka (1997) examined the usefulness of financial indicators to assess economic efficiency of the units within the State Forests. The suitability analysis was based on the essential indicators defining the financial situation of enterprises: liquidity, profitability, debt ratio and financial efficiency. The results obtained proved suitability of 11 commonly used financial performance indicators in efficiency assessments carried out in the forest districts. Consistent with the author, the indicators such as liquidity, debt and financial efficiency should be treated as important criteria for assessing the operations of forestry entities. 
Buraczewski (1996) analysed the property status and financial situation of the forest districts within the State Forests, based on the annual financial statements (balance sheet, profit and loss account). The results were presented as the functions: informative, comprehensive and evaluative; the fulfilment of these functions could enhance the improvement of the forest districts' operations.

In other studies, Buraczewski and Wysocki $(1997,2000)$ used the taxonomic method of linear ordering to assess the economic situation of forestry entity based on the synthetic measure of development. The values of this indicator made it possible to evaluate a given enterprise as compared to other analysed enterprises as well as to categorise the enterprises with respect to their financial condition. The usefulness of the proposed method for assessing the economic efficiency of forest districts was confirmed. The proposed approach enabled the preparation of a ranking of the forest districts according to their financial results.

Studies regarding the effects of nature-forest conditions (including the dimension and structure of economic tasks) on the management efficiency in organisational units of the State Forests (the so-called 'categorisation') were initiated by Patalas (1987) and constituted the basis for calculating the difficulty index. Kocel and Kwiecien (2006) continued the research in this area and developed the method for determining the difficulties in the management of forest districts, based on 14 sub-indices, which described the amount, structure and distribution of forest resources, terrain difficulties, a degree of risk to resources, as well as the dimension and structure of economic tasks. On the basis of these, a synthetic degree of difficulty in managing the forest districts and the Regional Directorates of the State Forests was determined (Kwiecien, Kocel, 2006). Next, the authors developed the method for determining the synthetic indicator of the effects of management of natural, human and economic resources of the forest districts (Kocel, Kwiecien 2010). The obtained results showed that nature-forest factors had a dominant influence on the effects of management, followed by economic and financial factors, whereas the factors related to human resources were relatively the least significant.

In the studies on forest sub-districts' efficiency, Kocel et al. (2012) tackled 16 partial indices that determined the level of management difficulty (stopień trudności gospodarowania, STG) in relation to the management conditions and the extent of economic tasks performed. The authors concluded that the method developed could be put into practice in the State Forests, in decision-making processes as to optimisation of the number of the forest sub-districts and the number of their employees, or else as regards functional allowances for managers of forest sub-districts.

Taking into consideration differentiated natural conditions, Lysik (2005) carried out the analysis and assessment of financial situation of forest districts localised within the areas of three Regional Directorates of the State Forests (in Katowice, Kraków and Krosno). The study included ratio analysis of the surveyed units as well as the determination of the synthetic measure of development and the synthetic cost indicator. The obtained results confirmed the influence of forest management in diversified natural and economic conditions on financial results of the forest districts. It was shown that unit costs increased with increasing share of upland and mountain sites within the area of the forest districts examined. The possibility of describing the financial situation of the forest districts using the synthetic development measure was also confirmed.

Czerwińska-Kayzer (2014) conducted a study to assess the financial efficiency of the Regional Directorates of the State Forests in 2011. The author used a multi-criteria decision analysis method (Technique for Order of Preference by Similarity to Ideal Solution -TOPSIS) to evaluate the financial performance of the examined Directorates. On the basis of the value of the synthetic measure, there were distinguished 3 classes of the Directorates with a given financial situation. The results obtained showed big differences between the Directorates in terms of financial efficiency. As stated by the author, financial efficiency of the Regional Directorates of the State Forests could be enhanced through involving different management manners.

\subsection{Parametric approach}

So far, the parametric methods have been intermittently used in the assessments of forest management efficiency. A study by Lee (2005) was carried out using SFA and non -parametric DEA for measuring and comparing technical efficiency of 79 forestry as well as pulp and paper enterprises located in 10 different regions or countries. In both the methods, the sum of assets, the total number of employees and capital were taken as input and the total sales revenue constituted output. The basic DEA model and the two-stage DEA model were used for the analysis of efficiency. Notwithstanding the assessment method used, the highest technical efficiency of the surveyed enterprises was observed in Japan, whilst the lowest was observed in Latin American countries.

The study by Siry and Newman (2001) presents the results obtained with the use of the SFA method to assess the impact of economic transformation (privatisation) in Poland on technical efficiency in 40 forest districts in the years 1993-1995. In the analysis, the authors used the stochastic frontier production function to assess the efficiency of timber production and forest management. The empirical results showed significant technical inefficiency that was not effectively eliminated by the establishment of the Regional Directorates of the State 
Forests or reduction of manual labourer positions. The results showed that at the beginning of the 1990s, the average Polish forest district achieved 50\% technical efficiency. The most significant reason behind the inefficiency observed was too high occupation rate of posts in the forest district administration. The results of the study confirmed the need to employ private companies to perform forestry works.

\subsection{Non-parametric approach}

The use of non-parametric methods to assess forest management efficiency has been described mainly in foreign literature on the subject. In Poland, not more than a few studies have been carried out in this area (Młynarski, Prędki 2016a, b, 2017).

The non-parametric DEA method was used by Kao and Yang (1991) for assessing the efficiency of entities associated with forestry. The study was carried out during the period of 10 years (1978-1987), in 13 forest districts in Taiwan, with the use of 4 input and 4 output variables. Input variables consist of forest district budget, initial employment, the total number of employees and the area of forest land. Production of wood, production of by-products, soil protection and recreation were treated as output variables. The results of the study showed that depending on the assessment model, some of the examined forest districts proved to be ineffective. The study was the first recognised example indicating that DEA can be a good tool for assessing and planning forest management activities.

Subsequent studies undertaken by Kao and Yang (1992), Kao et al. (1993) and Kao (1998) used the results of the aforementioned works by Kao and Yang (1991) and focused on the assessment of the efficiency of 13 forest districts, 3 years after the reorganisation of Taiwan's state forests. The obtained results showed not more than a small improvement in the efficiency of the forest districts examined. Almost a decade later, Kao (2010) expanded his research by assessing the efficiency of the forest districts by means of two conceptual approaches. The first approach allowed to assess the efficiency of an individual DMU at two points in time (then the unit examined was treated as two separate DMUs). The ratio of the values of efficiency indicators determined at different points in time illustrated changes in the efficiency of individual DMUs. The second conceptual approach was based on the use of Mälmquist index to assess the productivity of the forest districts studied. Both the conceptual approaches used in the assessments proved that in the years 1988-1992, there was improved efficiency of the forest districts under the study.

Shiba (1997) used the DEA method to determine the efficiency of the activities of forest owners' associations in Japan, focusing mainly on the measurement technique and a few key issues that arise when using DEA in practice. According to this author, the basic stage in building DEA models was to identify the effects and expenditures of the assessed units. Variables should reflect all the assets used for operations of a given unit, in comparable amounts for all the units being assessed. The author also pointed out that DEA models can be adapted to achieve specific goals by setting individual variables.

The issue of measuring efficiency of forest management by means of DEA was also analysed by Vitalla and Hänninen (1998). The aim of this study was to measure the efficiency of 19 state regional forest chambers in Finland. The efficiency of a given forestry chamber was determined as the weighted average of the efficiency indicator values, determined for each of the six areas of the chamber activity. The areas included planning and maintenance of forest roads and drainage ditches, preparation of forest management plans as well as training and development. In addition, the study used the Tobit model to determine the factors affecting chamber efficiency. The factors were divided into two groups: internal factors (motivation, organisation and characteristics of employees) and environmental factors (socio-economic characteristics of clients and climatic conditions). The results showed that in view of management efficiency, internal factors such as management manner and employee assistance programmes were the most important. Important relationships between the efficiency of the chambers studied and environmental factors were also demonstrated.

Bogetoft et al. (2003) used DEA to optimise the activities of the Danish Forestry Extension Service. For each local service office examined, three output variables were adopted: the annual economic surplus generated, the annual surplus generated for the benefit of employees and the annual sale of seedlings to private forest owners. All administrative costs were considered as input. The results showed widespread inefficiency. As said by the authors, the efficiency might be improved through mergers; however, the employees' reluctance to consolidate made it difficult to get out of the crisis. The authors proposed replacement activities, such as dissemination of know-how, cooperation between neighbouring offices and a change in the scale of operations of individual units.

The DEA method has also found application in the forest management in Iran. Limaei (2013) examined the efficiency of 14 Iranian forestry companies and forest management units. Overall production was divided into the processes and analysed by a two-stage DEA model. The first stage concerned the process of wood harvesting, with input represented by fixed costs and variable costs and output represented by revenue from wood sales. The second stage covered the marketing process with the result of the first stage as input, and the revenue and profit from wood sales were treated as 
output. The results showed that the studied forestry enterprises were able to increase the efficiency of their management by decreasing operating costs.

The study by Korkmaz (2011b) focused on measuring the efficiency (partial and total) of state forest enterprises in the Mediterranean region of Turkey. Partial efficiency was determined separately as three production factors (capital, labour and land). The total efficiency was the sum of the performance indicators of the factors under the study. The highest partial efficiency was demonstrated by the units in the capital group (75\%), followed by those in the land group (71\%) and the labour group (68\%). The non-parametric DEA method proved to be effective in the assessment of forest enterprises, and the obtained results allowed to determine the least and the most efficient units. Korkmaz (2011a) pointed out the possibility of using the Mälmquist index under DEA to determine the changes in the efficiency of 6 forestry enterprises during the period 2006-2010. Then, using three types of inputs and two types of outputs, the author assessed the technical efficiency changes, technological changes as well as scale efficiency. Most of the surveyed forestry units turned out to be ineffective in terms of management and production. At the same time, the technological changes introduced did not notably affect the efficiency improvement. The results confirmed that there is a lack of clear rules and regulations in the forest production process.

The important study on the use of the DEA method in assessing the forest management efficiency was carried out by Mörec and Jeromel (2011). These authors used DEA to determine the efficiency of 14 state-owned forestry companies in Slovenia. Technical efficiency was determined using four models: wood harvesting, silviculture and forest infrastructure, wood harvesting and silviculture as well as wood harvesting and wood exporting. Three more models (wood harvesting, wood harvesting and silviculture as well as wood harvesting and exporting) were used to determine the cost efficiency. The results showed low efficiency of forest management and confirmed the hypothesis that enterprises operating in the areas with small forest cover are technically and economically inefficient. As said by the authors, it would be reasonable to consider a reduction in the number of concessions granted for forest management, whilst increasing the area of activity of an individual enterprise.

The DEA method was also used by Kovalčík (2011) to assess Slovakia's forest management. The author carried out the analysis of management efficiency in 36 forestry service units, who conducted silvicultural and wood harvesting activities. The study covered 7 state-owned and 29 private enterprises. On the basis of the four input variables and two output variables, two models of efficiency assessment were built: technical and economic ones. In addition, a cost-bene- fit analysis was carried out; the results of this analysis were weighed against the results of efficiency assessment. The enterprises representing the economic model showed greater efficiency than those in the technical model. In terms of efficiency, the noteworthy advantage of state-owned enterprises over private companies was demonstrated. The analysis proved the convergence of the results of the cost-benefit analysis with the results of efficiency assessment by means of DEA, assuming constant effects of the scale.

The study by Yang et al. (2016) discusses the results of the analysis of changes in efficiency of 135 forestry enterprises in China during the years 2001-2010. Efficiency was estimated using the DEA model, and the Mälmquist index was used to determine the efficiency changes. The results showed an increase in the efficiency during the analysed period, which was mainly due to technological progress. The highest average growth rate of the Mälmquist index was recorded in the north-western part of the country. This was due to the investments by government in science and technological development, which enhanced the improvement of forest management in this area.

Several studies on the changes in forest management efficiency were carried out, depended on the changes in the country's legal or political situation. Zhang (2002) used the DEA method to assess the impact of economic reforms on the efficiency of 40 state forest offices in China during the years 1995-1997. The efficiency of the majority of organisational units had deteriorated, which indicated a high potential for improvement on account of further reforms. However, economic changes positively influenced the efficiency of some offices, which could be due to a reduction in administrative costs. As said by the author, the results of the presented analyses should be considered as an introduction to further research, because other factors might also affect the change in efficiency, including wages, employee competences, environmental and forest conditions and changes in silvicultural methods.

Using the DEA method, Managi (2005) examined the effects of government subsidies on forest management efficiency in Japanese regional administrative units during the period from 1975 to 2000 . The results showed that forest management efficiency decreased over the 25 -year period. The hypothesis was confirmed that government subsidies had negative effects on the economic performance of the forest sector - management efficiency decreased with increasing subsidies. However, the author pointed out that because of the dynamics and complexity of forest ecosystems, the obtained results should be interpreted with great caution.

Mack and Schoenenberger (2008) described the influence of the federal government's subsidy scheme on timber production efficiency in state-owned forestry enterprises in Switzerland. Government subsidies were granted to support the protection and management of forest stands, damaged 
in 1999 by the violent European windstorm Lothar. The efficiency of forestry units during the period 1998-2003 was estimated using the DEA model. It was shown that a year after the hurricane, the subsidies influenced forest enterprise efficiency not more than in one canton. In other cantons under the study, no effects of financial support on enterprise efficiency were observed.

Młynarski and Prędki (2016a, b, 2017) used the DEA method to analyse the efficiency of forest management in Poland. The authors assessed the financial efficiency and economic resources of the forest districts based on the assessments carried out in four Regional Directorates of State Forests (Wrocław, Katowice, Kraków and Krosno). The study was carried out in the groups of the forest districts with similar types of forest sites, which ensured uniformity of the units examined and comparability of the results obtained. Two categories of the forest districts were distinguished: 'lowland' and 'highland-mountain'. The results showed differentiation of the forest districts in terms of making use of financial inputs and economic resources. Lowland forest districts proved to be more efficient than those of highland-mountain in both the use of financial outlays and production factors (resources).

\section{Conclusion}

The analysis of subject literature revealed gaps in research on the efficiency of forest management in Poland. So far studies carried out in Poland have been based mainly on the methods involving indices and linear ordering measures determined based on the depicted indices. These studies often used group of methods that have addressed very diverse issues. It should be noted, however, that although the assessment based on indices has been widely used in practice, at a scientific level, the approach to efficiency assessment in Poland differs from current European and global trends. In Poland, studies that have been carried out with the use of parametric and non-parametric methods for assessing forest management efficiency are scarce. These methods are more advanced in terms of mathematical and statistical tools, which provide opportunities to carry out wide-ranging analyses, such as the analysis of the effects of the districts' scale or the analysis of changes in efficiency over time using the Mälmquist index.

The search for new methods for assessing the activities of the State Forests' entities and attempts to deepen the analysis of management efficiency may contribute to more competent management of state-owned forestry units. Therefore, studies that principally involve non-parametric evaluation of the forest districts' efficiency ought to be continued with the main focus on the analysis of financial efficiency and eco- nomic resources. The results of such studies could enable the determination of the maximum forest-derived income from selling wood (financial efficiency) and the maximum possible wood production (efficiency of economic resources).

\section{Conflict of interest}

The authors declare no potential conflicts.

\section{Acknowledgments and source of funding}

This article presents the results of research carried out as part of the project 'Identification of factors affecting the efficiency of management of the forest districts in the Regional Directorate of the State Forests in Wrockaw using the DEA method' (No. 22-04-01) financed in 2014-2015 by the Ministry of Science and Higher Education.

\section{References}

Andrzejczyk A. 1979. Postulaty metodyczne i rezultaty rachunku efektów produkcji drewna na pniu w drzewostanach sosnowych. Sylwan (123)5: 1-12.

Arbatowski S., Parzuchowska J., Kwiecień R. 1994. Wariantowa ocena efektywności Lasów Państwowych. Dokumentacja Instytutu Badawczego Leśnictwa, Warszawa, $25 \mathrm{~s}$.

Bańko M. (red.) 2005. Słownik wyrazów bliskoznacznych PWN. Wydawnictwo Naukowe PWN, Warszawa, 1-1011. ISBN 83-01-14377-0.

Bańko M. (red.) 2010. Słownik wyrazów obcych PWN. Wydawnictwo Naukowe PWN, Warszawa, 1-1348. ISBN 978-83-01-14455-5.

Bellinger W.K. 2007.The Economic Analysis of Public Policy. Routledge, London, 1-435. ISBN 978-0-415-77278-5.

Bielski M. 2004. Podstawy teorii organizacji i zarządzania. C.H. Beck, Warszawa, 1-231. ISBN 83-7387-441-0.

Bogetoft P., Otto L. 2011. Benchmarking with DEA, SFA and R, Springer, New York, International Series in Operations Research \& Management Science 157: 1-35.

Bogetoft P., Thorsen BJ., Strange N. 2003. Efficiency and merger gains in the Danish forestry extension service. Forest Science 49(4): 585-595. DOI 10.1093/forestscience/49.4.585.

Buraczewski A. 1996. Próba analizy stanu majątkowego i finansowego Nadleśnictwa Lasów Państwowych opartej na rocznym sprawozdaniu finansowym. Prace Komisji Nauk Rolniczych i Komisji Nauk Leśnych 82: 27-37.

Buraczewski A., Wysocki F. 1997. Próba zastosowania metod statystycznej analizy porównawczej do oceny sytuacji finansowej nadleśnictw. Prace Komisji Nauk Rolniczych i Komisji Nauk Leśnych 84: 7-15.

Buraczewski A., Wysocki F. 2000. Ocena sytuacji finansowej nadleśnictw za pomocą syntetycznego miernika rozwoju. Sylwan (144)1: 43-51. 
Charnes A., Cooper W.W., Rhodes E. 1978. Measuring efficiency of decision making units. European Journal of Operational Research 2: 429-444.DOI 10.1016/0377-2217(78)90138-8.

Czerwińska-Kayzer D. 2014. Zróżnicowanie efektywności finansowej w Regionalnych Dyrekcjach Lasów Państwowych w roku 2011. Sylwan 158(3): 163-172.

Ćwiąkała-Małys A., Nowak W. 2009. Wybrane metody pomiaru efektywności podmiotu gospodarczego. Wydawnictwo Uniwersytetu Wrocławskiego, Wrocław, 1-262. ISBN 978-83-229-3082-3.

Dudycz T., Wrzosek S. 2003. Analiza finansowa. Problemy metodyczne w ujęciu praktycznym. Wydawnictwo Akademii Ekonomicznej we Wrocławiu, Wrocław, 1-129. 83-70-11643-4.

Guzik B. 2009. Podstawowe modele DEA w badaniu efektywności gospodarczej i społecznej. Wydawnictwo Uniwersytetu Ekonomicznego, Poznań, 1-296. ISBN 978-83-74-17368-1.

Kao C. 1998. Measuring the efficiency of forest districts with multiple working circles. Journal of the Operational Research Society 49: 583-590.DOI 10.1057/palgrave.jors.2600570.

Kao C. 2010. Mälmquist productivity ratio based on common-weights DEA: The case of Taiwan forests after reorganization. Omega 38: 484-491. DOI 10.1016/j.omega.2009.12.005.

Kao C., Chang P., Hwang S.N. 1993. Data Envelopment Analysis in Measuring the Efficiency of Forest Management. Journal of Environmental Management. 38(1): 73-83.DOI 10.1006/ jema.1993.1030.

Kao C., Yang Y. 1991. Measuring the Efficiency of Forest Management. Forest Science 37(5): 1239-1252.DOI 10.1093/ forestscience/37.5.1239.

Kao C., Yang Y.C. 1992. Reorganization of forest districts via efficiency measurement. European Journal of Operational Research 58: 356-362. DOI 10.1016/0377-2217(92)90066-I

Klocek A. 2003. Ekonomiczne problemy gospodarstwa leśnego, w: Drzewostany świerkowe stan, problemy, perspektywy rozwojowe (red. A. Grzywacz ), Sesja Naukowa PTL, Ustroń-Jaszowiec, Polskie Towarzystwo Leśne, Warszawa, s. 23-39.

Klocek A., Płotkowski L. 2009. Zagadnienia przyszłości ekonomiki leśnictwa, w: Społeczno-ekonomiczne uwarunkowania przyszłości polskiego leśnictwa. Polskie Towarzystwo Leśne, Gorzów Wielkopolski, s. 109-129.

Kocel J. 2013. Firmy leśne w Polsce. Centrum Informacyjne Lasów Państwowych, Warszawa, 1-332.ISBN 978-83-61633-94-5.

Kocel J., Kwiecień R. 2010. Metoda określania syntetycznego wskaźnika efektów gospodarowania zasobami przyrodniczymi, ludzkimi i ekonomicznymi nadleśnictw. Leśne Prace Badawcze 71(1): 91-104. DOI 10.2478/v10111-010-0007-0.

Kocel J., Kwiecień R., Młynarski W., Mionskowski M. 2012. Wskaźnik stopnia trudności gospodarowania leśnictw Lasów Państwowych. Sylwan 156(6): 403-413.

Korkmaz M. 2011a. Measuring the productive efficiency of forest enterprises in Mediterranean Region of Turkey using data envelopment analysis. African Journal of Agricultural Research 6(19): 4522-4532.DOI 10.5897/AJAR11.1002.

Korkmaz M.2011b. Productivity changes of forest enterprises in Turkey: A non-parametric Malmquist approach. African Journal of Agricultural Research 6(28): 6189-6196.DOI 10.5897/ AJAR11.1355.
Kosieradzka A. 2004. Metoda wielokryterialnej oceny produktywności. Zarządzanie Przedsiębiorstwem, Leksykon PWN 2: $37-45$.

Kovalčík M. 2011. Hodnotenie efektívnosti hospodárenia na lesnej pôde. Lesnicky Časopis - Forestry Journal 57(3): 166-177.

Kwiecień R., Kocel J. 2006. Metoda określania stopnia trudności gospodarowania nadleśnictw. Leśne Prace Badawcze 2: 51-71.

Lee J-Y. 2005. Measuring production efficiency for forest and paper companies in the world - application of SFA and DEA approach. Forest Products Journal 55(7/8): 51-56.

Limaei S.M. 2013. Efficiency of Iranian forest industry based on DEA models. Journal of Forestry Research 24(4): 759-765.

Lysik K. 2005. Wpływ warunków przyrodniczych i wybranych czynników ekonomicznych na sytuację finansową nadleśnictw w RDLP Katowice, Kraków i Krosno. Maszynopis pracy doktorskiej. Akademia Rolnicza w Krakowie, Wydział Leśny, Kraków.

Mack A., Schoenenberger A. 2008. Technische Effizienz der öffentlichen Forstbetriebe in der Schweiz und Auswirkungen der Subventionen. Die Volkswirtschaft: das Magazin für Wirtschaftspolitik 81(6): 16-19.

Managi S. 2005. Evaluation and Policy Analysis of Japanese Forestry. Proceedings American Agricultural Association Annual Meeting, Providence, Rhode Island, July 24-27, 2005, 1-24.

Marszałek T. 1974. Efektywność gospodarki leśnej. Sylwan 118(10): 8-16.

Marszałek T. 1975. Efekty i efektywność gospodarki leśnej. PWRiL, Warszawa, 1-167.

Młynarski W., Prędki A. 2016a. Ocena efektywności technicznej i finansowej wybranych nadleśnictw lasów państwowych za pomocą metody DEA. Prace Naukowe Uniwersytetu Ekonomicznego we Wroclawiu 446: 126-143. DOI 10.15611/ pn.2016.446.10.

Młynarski W., Prędki A. 2016b. Zastosowanie metody DEA w ocenie efektywności gospodarowania nadleśnictw - orientacja na produkty. Quantitative Methods in Economics 17(2): 86-100.

Młynarski W., Prędki A. 2017. Metoda DEA w badaniu efektywności nadleśnictw. Sylwan 161(12): 1018-1025.

Mörec B., Jeromel, K. 2011. The efficiency and performance analysis of Slovenian forest enterprises. Proceedings of 8th International Conference "Economic Integration, Competition and Cooperation", 6-9 April, Opatija, University of Rijeka, 1-15.

Patalas Z. 1987. Współczynniki trudności Wt dla nadleśnictw i OZLP. Prace Instytutu Badawczego Leśnictwa ser. A 663: 41-51.

Pawłowska M., Kozak S. 2008. Określenie wpływu przystąpienia do strefy euro na efektywność, poziom konkurencji oraz na wyniki polskiego sektora finansowego. Materiały i Studia 228, Narodowy Bank Polski, 1-54.

Podgórki M., Kikayi P.R. 1996. Próba określenia produkcyjności i produktywności lasu za pomocą wskaźników technicznych i ekonomicznych, na przykładzie nadleśnictw rRegionalnej Dyrekcji Lasów Państwowych w Szczecinie. Prace Komisji Nauk Rolniczych i Komisji Nauk Leśnych 82: 125-133.

Podgórski M. 1989. Efektywność produkcji leśnej „przy pniu” i „na pniu” w nadleśnictwach Lasów Państwowych. Prace Komisji Nauk Rolniczych i Komisji Nauk Leśnych 68: 61-68. 
Pomykalska B., Pomykalski P. 2007. Analiza finansowa przedsiębiorstwa. Wydawnictwo Naukowe PWN, Warszawa, 1-342. ISBN 978-83-01-14871-3.

Prędki A. 2003. Analiza efektywności za pomocą metody DEA: Podstawy formalne i ilustracja ekonomiczna. Przegląd Statystyczny 1: 87-100.

Pszczołowski T. 1978. Mała encyklopedia prakseologii i teorii organizacji. Ossolineum, Wrocław, 1-346.

Ray S.C. 2004. Data Envelopment Analysis. Theory and Techniques for Economies and Operations Research. Cambridge University Press, Cambridge, 1-366. ISBN 978-0-521-80256-7.

Samuelson P.A., Nordhaus W.D. 2017. Ekonomia. Rebis, Warszawa, 1-728. ISBN 978-83-75-10614-5.

Shiba M. 1997. Measuring the efficiency of managerial and technical performances forestry activities by means of DEA. Journal of Forest Engineering 8(1): 7-19.

Siry J., Newman D.H. 2001.A stochastic production frontier analysis of Polish state forest management. Forest Science 47(4): 526-533.DOI 10.1093/forestscience/47.4.526.

Spruch W. 1984. Problemy oceny efektywności gospodarowania przedsiębiorstwem w działalności kredytowej banku. Bank i Kredyt 10-11: 326-327.

Sulmicki P. 1978. Planowanie i zarządzanie gospodarcze. PWE, Warszawa, 1-406.

Szoege H.M. 2005. Zarys problemów ekonomiki środowiska. Wydawnictwo SGGW, Warszawa, 1-178. ISBN 83-7244-691-1.

Szramka H. 1982. Metodyka określania efektywności produkcji leśnej efektywności pracy w gospodarstwie leśnym. Praca doktorska. Akademia Rolnicza w Poznaniu, Wydział Leśny, Katedra Ekonomiki Leśnictwa, Poznań.

Szramka H. 1989. Analiza przydatności współczynników różnej konstrukcji do korygowania wskaźników efektywności pracy w gospodarstwie leśnym. Prace Komisji Nauk Rolniczych i Komisji Nauk Leśnych 68: 103-109.

Szramka H. 1992. Wstępna analiza podstawowych determinantów ekonomicznej efektywności pracy w gospodarstwie leśnym. Prace Komisji Nauk Rolniczych i Komisji Nauk Leśnych 76: 119-124.

Szramka H. 1995. Analiza sytuacji finansowej nadleśnictw Regionalnej Dyrekcji Lasów Państwowych w Szczecinku. Prace Komisji Nauk Rolniczych i Komisji Nauk Leśnych 80: 131-136.
Szramka H. 1996. Próba oceny sytuacji gospodarczej nadleśnictw po wprowadzeniu nowych zasad gospodarki finansowej w Lasach Państwowych. Prace Komisji Nauk Rolniczych i Komisji Nauk Leśnych 82: 143-149.

Szramka H. 1997. Przegląd i próba wyboru metod określania ekonomicznej efektywności bieżącej działalności gospodarczej jednostek Lasów Państwowych. Prace Komisji Nauk Rolniczych i Komisji Nauk Leśnych 84: 51-57.

Szymańska E. 2010. Efektywność przedsiębiorstw -definiowanie i pomiar. Roczniki Nauk Rolniczych, Seria G 97(2): 152-164.

Triantis K. 1990. An assessment of technical efficiency measures for manufacturing plants. People and product management in manufacturing, in: Advances in Industrial Engineering (ed. J.A. Edosomwan ). Elsevier Science Publishers, Amsterdam, s. 149-166.

Viitala E.J., Hänninen H. 1998. Measuring the efficiency of public forestry organizations. Forest Science 44(2): 298-307.DOI 10.1093/forestscience/44.2.298.

Wolszczak-Derlacz J. 2014. Efektywność naukowa, dydaktyczna i wdrożeniowa publicznych szkół wyższych w Polsce - analiza nieparametryczna. Wydawnictwo Politechniki Gdańskiej, Gdańsk, 1-190. ISBN 978-83-7348-523-5.

Yang H., Yuan T., Zhang X., Li S. 2016. A Decade Trend of Total Factor Productivity of Key State-Owned Forestry Enterprises in China. Forests 7(5): 97.DOI 10.3390/f7050097.

Zhang Y. 2002. The Impacts of Economic Reform on the Efficiency of Silviculture in China: A Non-Parametric Approach. Environment and Development Economics 7(1): 107-122.DOI $10.1017 / \mathrm{S} 1355770 \mathrm{X} 02000062$.

\section{Other}

Ustawa 1991. Ustawa z dnia 28 września 1991 r. o lasach. Dz.U. z 2015 r. poz. 2100 z późn. zm. [Act of 28 September 1991 on forests. Journal of Laws, 2015, item 2100 with later amendments].

\section{Authors' contribution}

W.M. - research conception, literature review, manuscript writing and editing;

A.K. - literature review supplementing, manuscript writing and editing. 